\title{
A Survey of Motivation Strategies in College English Classroom and the Selection of Effective Teaching Strategies
}

\author{
Jie Xiao \\ Department of Foreign Languages \\ Wenhua College \\ Wuhan, China \\ Luckycrystalxj@163.com
}

\author{
Zhong Cao \\ Administration of Construction Operation \\ Three Gorges Project \\ Yichang, China \\ cao_zhong@ctgpc.com.cn
}

\author{
Wei-Min Qi ${ }^{*}$ \\ School of Physics \& Information Engineering \\ Jianghan University \\ Wuhan, China \\ qwmin@126.com
}

\begin{abstract}
Motivation is one of the main factors influencing college students' foreign language learning. The theory of social mental model provided by Gardner\&Lambert puts forward that the social environment will affect the motivation of the second language learners' learning. Dornyei's theory of three levels model puts forward the hypothesis that students' English basic level will affect the effective implementation of motivational strategies. John M. Keller's ARCS model theory intending to stimulate and maintain the learning motivation proposes that motivation strategies should include attention strategy, relevance strategy, confidence strategy, and satisfaction strategy. Based on the above three sets of theory for guidance, this research designed questionnaire and investigated the English learning motivation of different levels of college students. Through the analysis of the survey data, the author summed up the good and bad motivation strategies of teaching, and found that different levels of students need different learning objectives and incentive strategies. Thus the author put forward the principles of choosing effective teaching strategies in College English class.
\end{abstract}

Keywords-questionnaire; motivation strategies; effective teaching strategy choice

\section{INTRODUCTION}

Canadian psychologists Gardner\& Lambert began to study the motivation of the second language learning in 1950s. Gardner proposes that language learning motivation refers to the desire of students to learn a certain language, the effort to achieve the goal of learning and comprehensive good attitudes towards learning a language, all of which, as non intellectual factors, are to promote the internal motivation of students to learn and to promote the role of learning. Gardner further points out that foreign language learning motivation includes the learning goal, learning effortful behavior, desires to attain the learning goal and the learning attitude. That is to say, only when the second language learner not only has the goal and a correct attitude towards language learning but also has made a hard effort in order to realize the desire of foreign language learning, he really possesses the foreign language learning motivation [1]. Gardner\& Lambert summarizes the motivation for foreign language learning as the instrumental motivation and integrative motivation. Instrumental motivation refers to that the second learner's motivation for foreign language learning is for other purposes and learning language is only a means to achieve its purpose. Integrative motivation refers to that the second learner's motivation for learning foreign languages is to integrate into the language of society so that he can communicate better with people who use them. Integrative motivation consists of three parts: integration, the attitude towards the learning environment, and motivation. The integration reflects the desire and interest of the learners to associate with the target language, and the attitude towards the learning environment includes the attitude towards the teacher and the attitude towards the foreign language curriculum. Motivation refers to the second learner's efforts in the learning process, the attitude towards learning and the expectation of learning ability and the learning result.

Dornyei's theory of three levels model has the following 3 aspects: language level, learner level, and situation level. Language level includes the power of each part of the foreign language learners, such as the language culture, language community and language practicality. These motivational factors determine the second language learners' the basic learning goals and language selection. Learner level refers to the characteristics of individual learner differences, including emotional and cognitive factors. Situation level includes the factors such as teachers and collective force. This model emphasizes that the motivation is influenced by the internal and external factors. Dornyei points out teachers' motivation strategies may not always be able to play a role, since the foreign language proficiency of different students is uneven, 
and it is very likely to be one of the important reasons that affect the effectiveness of foreign language learning motivation $[2,3]$.

John M. Keller's ARCS model theory intending to stimulate and maintain the learning motivation proposes that motivation strategies should include attention strategy, relevance strategy, confidence strategy, and satisfaction strategy. According to the ARCS model theory attention strategy, relevance strategy, confidence strategy, and satisfaction strategy mean attracting students' interest and stimulate students' curiosity, meeting the needs and goals of the students, making them have a positive learning attitude, helping students build up confidence, making the believe to have the ability to complete the task, and making students get the internal and external encouragement and reward because of learning achievement [4].

\section{DESIGN QUESTIONNAIRE}

Based on the above three sets of theory for guidance, this research designed questionnaire and investigated the English learning motivation of different levels of college students. The questionnaire investigated students in the English classroom, mainly including: (1)teacher's role in the eyes of students, and the teacher's and students' position in the classroom through statistical data of the questionnaire; (2)students' feelings about English classroom to prove the actual effect of motivation from the side; (3)collection of the motivation strategies used by teachers and the analysis of the dimensions and levels of each strategy. Through the above questionnaire, the author concluded the good and bad motivation strategies of teaching. A total of 30 items were used to investigate the practical application process and effect of motivational strategies in College English class. The questionnaire was made in the form of LIKERT five scales. Based on the classical theory of Attitude/Motivation Test Battery, this questionnaire referenced to the questionnaire of Jin Wenwen's master's degree thesis [5] and was modified according to the characteristics of College Students' foreign language learning. The questionnaire was mainly to investigate the dimensions and levels of each of the motivation strategies. The dimensions of each of the motivation strategies include teachers' own quality, creating a positive atmosphere in the classroom, arranging classroom tasks, creating harmonious atmosphere between teachers and students, making students confident, arousing students' interest, mobilizing the initiative of students, setting goals for students, making students understand the culture, organizing students to make group learning, promoting students' individual efforts, emphasizing the practical usefulness of English. The levels of each of the motivation strategies include learning situation level, learner level, and language learning level etc.. The questionnaire issued a total of 51 papers and 50 questionnaires were recovered effectively. The effective recovery rate reached to $99 \%$.

\section{ANALYSIS OF QUESTIONNAIRE RESULTS}

Before you begin to format your paper, first write and save the content as a separate text file. Keep your text and graphic files separate until after the text has been formatted and styled. Do not use hard tabs, and limit use of hard returns to only one return at the end of a paragraph. Do not add any kind of pagination anywhere in the paper. Do not number text headsthe template will do that for you.

A total of 60 people participated in the survey, including 25 male students and 35 female students. Data showed that the student level distribution reached to 1:1:1. Among high level students, 86\% of them feel relaxed and happy in English class; $59 \%$ of middle level students feel happy; $37 \%$ of low level students feel happy and 31\% feel depressed.

The proportion of teachers' role in the eyes of the students is shown in Table I :

TABLE I. PROPORTION OF TEACHERS' ROLE

\begin{tabular}{|l|l|l|l|l|}
\hline $\begin{array}{r}\text { Teacher' } \\
\text { Role }\end{array}$ & Controller & Participant & Guide & Organizer \\
\hline A/Top & $38 \%$ & $25 \%$ & $17 \%$ & $20 \%$ \\
\hline B/Middle & $42 \%$ & $21 \%$ & $15 \%$ & $22 \%$ \\
\hline C/Low & $46 \%$ & $12 \%$ & $18 \%$ & $24 \%$ \\
\hline
\end{tabular}

The top 5 effective motivation strategies in the eyes of the students in the upper reaches are shown in Table II :

TABLE II. EFFECtIVE Motivation StRATEgIES

\begin{tabular}{|l|l|l|}
\hline \multicolumn{1}{|c|}{ Observation Item } & Mean & \multicolumn{1}{|c|}{$\begin{array}{c}\text { Dimensions and Levels } \\
\text { of Each Strategy }\end{array}$} \\
\hline $\begin{array}{l}\text { 10. My teacher makes clear } \\
\text { the purpose and function of } \\
\text { the activity to students } \\
\text { before the study. }\end{array}$ & 4.75 & Classroom tasks \\
\hline $\begin{array}{l}\text { 25. My teacher tells } \\
\text { students that only personal } \\
\text { efforts can learn English } \\
\text { well. }\end{array}$ & 4.71 & Promote personal efforts \\
\hline $\begin{array}{l}\text { 3. My English teacher is } \\
\text { natural in class. }\end{array}$ & 4.70 & Teacher factor \\
\hline $\begin{array}{l}\text { 11.My teacher gets along } \\
\text { with student. }\end{array}$ & 4.60 & Harmonious atmosphere \\
\hline $\begin{array}{l}\text { 1.My teacher prepares each } \\
\text { lesson well. }\end{array}$ & 4.60 & Teacher factor \\
\hline
\end{tabular}

The top 5 effective motivation strategies in the eyes of the students in the middle reaches are shown in Table III.

TABLE III. EFFective Motivation StrategIES IN THE MiddLE REACHES

\begin{tabular}{|l|l|l|}
\hline \multicolumn{1}{|c|}{ Observation Item } & Mean & \multicolumn{1}{|c|}{$\begin{array}{c}\text { Dimensions and Levels } \\
\text { of Each Strategy }\end{array}$} \\
\hline $\begin{array}{l}\text { 11.My teacher gets along } \\
\text { with student. }\end{array}$ & 4.85 & Harmonious atmosphere \\
\hline $\begin{array}{l}\text { 25. My teacher tells } \\
\text { students that only personal } \\
\text { efforts can learn English } \\
\text { well. }\end{array}$ & 4.80 & Promote personal efforts \\
\hline $\begin{array}{l}\text { 29. My teacher regularly } \\
\text { emphasizes class discipline. }\end{array}$ & 4.60 & Classroom norms \\
\hline $\begin{array}{l}\text { 1. My teacher prepares each } \\
\text { lesson well. }\end{array}$ & 4.50 & Teacher factor \\
\hline $\begin{array}{l}\text { 2. My English teacher has a } \\
\text { passion for class. }\end{array}$ & 4.45 & Teacher factor \\
\hline
\end{tabular}


The top 5 effective motivation strategies in the eyes of the students in the lower reaches are shown in Table IV.

TABLE IV. EFFective MotiVAtion STRATEgIES IN THE LOWER REACHES

\begin{tabular}{|l|l|l|}
\hline \multicolumn{1}{|c|}{ Observation Item } & Mean & \multicolumn{1}{|c|}{$\begin{array}{c}\text { Dimensions and Levels } \\
\text { of Each Strategy }\end{array}$} \\
\hline $\begin{array}{l}\text { 25. My teacher tells } \\
\text { students that only personal } \\
\text { efforts can learn English } \\
\text { well. }\end{array}$ & 4.85 & Promote personal efforts \\
\hline $\begin{array}{l}\text { 1. My teacher prepares each } \\
\text { lesson well. }\end{array}$ & 4.60 & Teacher factor \\
\hline $\begin{array}{l}\text { 26. My teacher always } \\
\text { stresses that English is very } \\
\text { useful. }\end{array}$ & 4.50 & Emphasize usefulness \\
\hline $\begin{array}{l}\text { 11. My teacher gets along } \\
\text { with student. }\end{array}$ & 4.50 & Harmonious atmosphere \\
\hline $\begin{array}{l}\text { 29. My English teacher } \\
\text { regularly emphasizes class } \\
\text { discipline. }\end{array}$ & 4.40 & Classroom norms \\
\hline
\end{tabular}

The survey results show that different levels of students need different motivation strategies. The students in the upper reaches need integration motivation strategies, ie., teachers need to emphasize the integration of different cultures to those students, highlight the students' self efficacy, and stimulate students' intrinsic interest. The students in the middle reaches need motivational strategies of situational teaching, ie., teachers need to emphasize the students' individual interest needs, students' expectations and sense of self achievement, and highlight the affinity of teachers. The students in the lower reaches need ARCS motivational strategies, ie., teachers need to emphasize the students' confidence, pay attention to the students' satisfaction to the course, as well as enhance the students' attention to the course.

\section{PRINCIPLES OF EFFECTIVELY ChOOSING TEACHING STRATEGIES IN COLLEGE ENGLISH ClASS}

First, establish a good relationship between teachers and students and create a relaxed and harmonious classroom atmosphere. Mutual trust and mutual respect between teachers and students is the premise of building a harmonious classroom atmosphere. It is the key to harmonious classroom atmosphere to admit students' individual differences and affirm their efforts and to make the students get a sense of satisfaction. Only in a relaxed and harmonious atmosphere in the classroom, students can ensure ease of mind, dare to think, dare to criticize and free express their ideas and opinions.

Second, make students clear about the teaching goals and tasks. Before the class teacher should tell the students clearly about the learning objectives and tasks of this class and make students start learning with questions, so that the learning process of the passive acceptance can be changed into active absorption. In this way the teacher can stimulate students' interest in learning and improve the efficiency of learning.

Third, design teaching content carefully and pay attention to students' cooperative learning. When dealing with the specific teaching activities, if the teacher cannot take full account of the fellow students' learning division of tasks, teachers may not have enough classroom activities for all students because of the limitation of time, which will lead to negative emotions from the ignored students, such as depression, anxiety, fear and nervousness. Especially for students who lack confidence, they may become more timid and unwilling to express themselves in public. Cooperative learning can effectively solve such problems. Cooperative learning can make each level of students work together to complete the task of learning. All levels of students can learn from each other's learning mode, thinking mode, learning strategies, problem-solving methods and communication skills, so as to enhance their learning methods and ability levels. This activity can greatly enhance students' self-confidence, selfesteem and sense of achievement. Each level of students can improve their meta cognitive and cognitive level through the division of task.

Fourth, dilute the competitive environment, and improve the scoring mechanism. Competition can promote students to compare each other, which has a certain positive significance. However, excessive competition will make students rebellious and even disgust scores because of the pressure of the score. Therefore, in the classroom practice, teachers do not give the students a failing grade, or temporarily do not give the students a failing grade, until the students revise to a good score [5].

Fifth, teachers should transform the level of motivation into the intrinsic behavior of the students in a timely manner. The motivation implemented by teachers is transient and unstable. Under the environment of the absence of teachers' motivation students are easy to return to normal learning state. Therefore, the motivation strategy which cannot maintain students' active learning status is of no significance. Teachers' motivation strategies need to help students to realize their inner conscious learning, get rid of learning dependence, and master a better learning strategy [7].

Sixth, teachers should timely adjust learning objectives and focus on learning feedback. The learning objectives need to be adjusted in a timely manner according to the individual characteristics of the students. At the same time, teachers should give students learning feedback in a timely manner. This allows students to understand their own learning strengths and shortcomings, and to experience the results of their efforts and the direction of future efforts.

\section{CONCLUSION}

To study the practical application and effect of the motivation strategies in College English class and to put forward the principles of effective teaching strategies in College English class have certain enlightenment to college English teaching. The next research will focus on the practice of College English teaching, and the application of the different motivation strategies into the teaching of students at different levels in order to find a more effective teaching method.

\section{ACKNOWLEDGMENT}

This research was financially supported by the Educational and Scientific 12th Five-Year Planning Project of Hubei 
Provincial Department of Education, 2014 (Grant NO. 2014B311).

\section{REFERENCES}

[1] R. C. Gardner. \& W. E. Lamber, "Attitudes and Motivation in Second Language Learning,” Rowley, Mass: Newbory House, 1972.

[2] Z. Dornyei, "Motivation and motivating in the foreign language classroom," The Modern Language Journal, vol.78, pp. 273-284, 1994.

[3] Z. Dornyei, "Teaching and researching motivation," Beijing: Foreign Language Teaching and Reseach Press, 2005.
[4] J. M. Keller, K. Suruki, "Learner motivation and E-learning design: A Multinational Validated Process,” Journal of Educational Media, 2004.

[5] Wenwen Jin. "The effectiveness of secondary english teachers' motivational strategies: A Study Based on the Hierarchical Teaching Method," Hangzhou Normal University, 2013.

[6] Diankun Du. "Research on the School of Teaching Theory in the Former Soviet Union,” Shaanxi people's Education Publishing House. 1993.

[7] Yan Hu. "A study on the motivation strategies of learning motivation in the second language learning," Journal of Changsha University of Science and Technology, 2015. 